\title{
Enterococcus saccharolyticus
}

National Cancer Institute

\section{Source}

National Cancer Institute. Enterococcus saccharolyticus. NCI Thesaurus. Code C122301.

A species of Gram-positive, catalase-negative, facultatively anaerobic, fermentative, nonmotile, coccus-shaped bacteria in the family Enterococcaceae. 